\title{
The Legislative and Executive Institutions and the Challenge of Governance in Contemporary Nigeria
}

\author{
Kunle Awotokun ${ }^{1}$ \\ ${ }^{1}$ Local Government and Development Studies, Obafemi Awolowo University, Ile-Ife, Osun State, Nigeria \\ Correspondence: Kunle Awotokun, Local Government and Development Studies, Obafemi Awolowo University, \\ Ile-Ife, Osun State, Nigeria. Tel: 080-3723-4877. E-mail: kunleawotokun1@gmail.com
}

Received: June 24, 2020

doi:10.5539/jpl.v14n2p19
Accepted: October 8, $2020 \quad$ Online Published: December 22, 2020

URL: https://doi.org/10.5539/jpl.v14n2p19

\begin{abstract}
The article examines the efforts of the executive and the legislature, i.e. the National Assembly at providing good governance against the backdrop of daunting challenge of insecurity in contemporary Nigeria.

The paper employs secondary data to elicit necessary information to assist in its analysis and findings. Such data includes textbooks, journals, newspapers, magazines, periodicals etc.

The findings are that both executive and legislative institutions pay lip service to quality governance. The two arms of government are tendentious towards kleptocracy. This development has compromised their efforts at fostering good governance.

The work concludes on the need to convocate extra executive and legislature bodies (Sovereign National Conference) to discuss and analyse the contemporary questions with the aim of finding lasting solutions to the issues. The prognosis will not only be helpful to Nigeria but serves as a template for other African countries with similar issues.
\end{abstract}

Keywords: executive, legislative, governance, contemporary, Nigeria

\section{Introduction}

The Nigerian state has had to face daunting challenges in the last one decade, ranging from socio-economic, poor leadership, momentary decline of security architecture leading to insecurity of life and property, etc. The issue of poor governance has no doubt culminated into socio-economic and political infractions which have festered over time, resulting in militancy in the Niger Delta, kidnapping in the Southeast, armed robbery in the southwest, ethnic/religious violence in the Plateau, Herdsmen-farmers imbroglio in the North-central, banditry, urchin (Almajiri) in the Northwest and Boko Haram operations in the Northeast. Indeed, all afore-mentioned have threatened the corporate existence of the country as many see the country as sliding into a failed state. What has been the involvement of the legislature and the executive in the scenario? How can the Nigeria's legislative and executive arms exculpate themselves from the political logjam? These and other issues are what this work seeks to address.

\section{The Presupposition of the Paper and Conceptual Clarifications}

The premise of this work can be established on the basis that the Nigerian constitutional democracy has been patterned towards the presidential system of government. The presidential system operates essentially on a tripartite system of governance namely, the legislature, the executive and the judiciary, which in most cases, is expected to work in tandem for the good governance of the society. However, it must be understood from the onset that the legislature and the executive are the two branches of government that are entrusted with the governance of the political domain. The judiciary which is the third branch is expected to interpret the law and resolve conflicts that may arise between the legislature and executive.

The concern of this paper is to analyse the political process of governance in the legislature and the executive since the two arms of government are expected to administer the people through law-making (legislature) and execution of laws and regulations which fall under the purview of the executive. Constitutional democracy expects the operators of the legislative or national assembly and the presidency (executive) to emerge through the people's mandate, hence the reference to democracy as government of the people, by the people and for the people. Another 
expectation of democracy is that the people should be able to hold the elected officials (both the legislature and the executive) accountable in the governing process of the society. It is on this premise that this work is situated.

Be that as it may, it is the intention of the paper to operationalise some concepts germane to this work, such as legislature, executive and governance.

Much as attempts will be made to define some concepts germane to this work, it must be stated that there is, perhaps, no clear-out definition of any concepts in social sciences of which this work is an integral part. However, this work will adopt what is termed as a working definition, designed but not limited, to understanding the frame work of this paper. Hence, legislature can be broadly defined as the accredited representatives of the people in the legislative or law-making institution in a democratic government. In the process of legislating for good governance, they are expected to make laws and aggregate the executive functions (Awotokun, 2019). The legislators are meant to interact with the executive from time to time in socio-political relationship in order to engender good governance. It is this pivotal role of the legislators that makes people to refer to democracy as a system of government in which the representatives are chosen by free competitive election (Birch, 1993).

In the context of Nigeria's constitutional democracy, the legislature is seen as the symbol of democracy; its members represent different strata of the Nigerian society and therefore are expected to check the executive because of the enormous power of the President as the Head of government and commander-in-chief of the Armed Forces including the police force of the federation. For instance, the Constitution (1999) empowered the legislature to ratify certain categories of presidential appointments such as federal ministers (who constitute the cabinet), special advisers, chief justice of the federation, ambassadors, high commissioners and other principal representatives of the country abroad. The sub totality of this is what Awotokun (1998) referred to as legislative power to control the executive.

The legislature also possesses the investigative power to inquire into the affairs of any government agencies in the federation. For the purpose of oversight function over the executive, the legislature often raises their ad hoc committees in line with the existing ministries at the federal and state level.

It is instructive to note that despite this enormous power of the National Assembly, there are no remarkable things that are accomplished by the legislature in the area of accountability, transparency, responsibility and responsiveness of the executive to the people. Indeed, it appears that there is conspiracy between the legislative and executive institutions to inflict socio-economic problems on the people. In the main, it appears from all indications that the executive has prevailing power over the legislative institutions, because the latter have remained docile in the face of vociferous influence of executive branch.

The executive branch, like the legislature is elected to execute the laws and policies once validly enacted by the legislature. The executive members, unlike the legislature, are not numerous. The executive usually consists of elected governors, deputy governors, president and vice president, members of the cabinet and the bureaucratic apparatus of the state. The bureaucracy assists the political executives to implement the programmes of the state. In other words, the executive, as in the words of Awotokun (2019), encompasses the political executives, governors, deputy governors, president, vice president, commissioners, ministers, special advisers, the bureaucracy and all those saddled with the execution of the functions of government with the exception of the legislature and the judiciary.

It must be emphasized that there are a good number of differences between 'government' and governance. Government according to (Merriam-Webster Dictionary 2013) amounts to the group of people who controls and makes decisions for a country, state, etc. In a sense, this people can be referred to as political elite, who are the custodians of the machinery and apparatus of the state. Hence, government refers to things that are public or statecentered. In other words, government may be conceived as a body of elected or appointed representatives who are saddled with the control of governmental apparatus for the purpose of providing for and promoting the social and material well-being of the people in a given political ecology. In this sense, we refer to a democratic system of government in which a group of people through the membership of political parties secure the people or public mandate to run the affairs of a state or country with a well-defined term or duration of office. Democratic governments are more often than not marked by periodic elections; adherence to rule of law as enacted by the legislature, respect for the constitution, insulation of judiciary from politics, etc. When all these are put in place, the polity will produce good governance. Hence, governance becomes a by-product of governmental actions.

Hence, governance is a synergy between governmental efforts and other societal institutions for political, social and economic well-being of the people over a period of time. On this note, the World Bank has identified three dimensions or components of governance namely the nature of political regimes, the exercise of authority in the management of socio-economic resources, and the government capacities on policy formulation and 
implementation, as well as effective service delivery.

For instance, the World Bank (1992) focused on the public sector in its attempt to give a contextual meaning to governance. It is largely conceived as a way in which power is operationalized in the management of economic and social resources of a country (Awotokun, 2020).

For Olaiya T. A. et.al (2019), good governance is seen as the capability of the government of a state to institutionalize the rule of law, accountability and responsible practices in the annals of all state apparatuses. In the case of Keping (2018), he amplified and identified good governance from six different but mutually reinforcing perspectives or variables namely legitimacy, transparency, accountability, rule of law, responsiveness and effectiveness. Hence, governance stands to interrogate the legitimacy of the government in power: is the process of governance transparent for all to see? How accountable are the governing elite? Is there adherence to the constitution of the state or the inviolability of the constitution? The responsiveness may translate to the readiness of government to address critical questions of the state; and the effectiveness finally translates to good governance.

Therefore, governance is a process of bringing the government and the people, stakeholders, civil societies, etc., together in order to ameliorate the objectionable conditions of the people. It is an interventionist policy to improve security of lives and properties, engineering and re-engineering of public roads, feeder roads, schools, hospitals, empowerment, ecological sanitation, and so on. When all of the aforementioned are put in place, we talk of good governance, while the absence will attract public outcry. At this stage, it will be apposite to make some distinction between government and governance.

\section{The Dichotomy between Government and Governance}

The terms government and governance are mutually inclusive in the sense that the two concepts seek to find the challenge of statecraft. However, in some respects, there are differences between them. It is these differences that this paper intends to illustrate shortly.

Whereas government is usually designed to be formalized, hierarchical, and constitutionally based, its formalization and constitutionalism and adherence to rule of law depend largely on the political operators (usually the executive and legislative arms). The legislature formulates and the executive executes (implements) governmental policies after the legislature has passed them to law. In some cases where you find a combination of executive despots and docile legislative institutions in a polity, government will be boring, unaccountable and therefore anathema to the people.

Governance, on the other hand, may or may not be formalized, but it usually underscores synergy between the governmental apparatus and the people (the end users) in the promotion of socio-economic and political wellbeing, including the wellness of the people over a period of time.

Government emphasizes budget and budgetary process in the provision and allocation of socio-amenities to the people. In the process, the allocation is subjected to politics. It is a question of what David Easton (1965) described an "authoritative allocation of values or distribution of rewards". The allocation and distribution of reward in Nigeria are more often than not based on primordial considerations, ethnicity, religion, political affiliation or membership, etc. This is the bane of the inability of the Nigerian political elite to provide dividends of democracy to all and sundry.

The concern of governance is the general well-being of all, regardless of ethnicity, religion or political affiliations. Governance sees the fallout from the state as inalienable rights of all; that in a way constitute the end product of its visions.

Government in Nigeria is highly elitist, distant, arrogant and snobbery and therefore can be described as a topbottom approach to statecraft. Governance, on the other hand, underscores bottom-up mechanism towards addressing the environmental issues. More so in many cases, some challenges may not have been envisaged hitherto, but have to be tackled especially if they are life threatening such as floods, health hazards, environmental degradation resulting in pollution, etc. Governance therefore provides a more dynamic approach towards operationalizing statecraft such that people are harmonized towards the sharing of commonwealth.

At this juncture, if a distinction must be drawn between good and bad governance, then Nigeria will be qualified for the latter. In order to justify the assertion, there is need to highlight the features of societal ills as presently manifested in Nigeria's political landscape. In other words, what are the identifiable overarching issues in contemporary Nigeria that have constituted a burden to governance?

\section{The Burden of Governance}

The Nigerian state faced a myriad or litany of problems soon after the inauguration of the fourth republic. Some 
of them had been on ground since the military era, but only waiting for appropriate time to ventilate them. Prominent among these issues are politics of resource control, ethnic militarism or militia corruption, National conference, the Constitution, National Security and so on. Let us begin to operationalize some of these issues. Resource control, became a thorny issue following the discovery and prospecting of petroleum and its allied products in Nigeria. The prospecting of petroleum was soon followed by environmental degradation of the Niger Delta area where the petroleum had been found in large quantity. Following the wide publicity occasioned by the plight of the people owing to oil spillage, there arose insurrection from the people of the region, especially the youth. Hence, there was a high rise of ethnic militia in the South-South geo-political area of Nigeria, such as Bakassi Boys, the Ijaw formed 'Egbesu', Niger-Delta Liberation Army, etc.

The blatant and brazen manner in which General Ibrahim Babangida treated the June 12, 1993 election, which Chief Moshood Abiola won, led to the formation of O'odua People's Congress (OPC) by the Yoruba youth. The Hausa-Fulani of the North also hurriedly formed Arewa People's Congress (APC) as a counter-poise to the threatening insurgence from the other parts of the country.

The Igbo who constituently orchestrated their marginalisation, since Nigeria's independence in 1960, had agitated for a separate sovereign state of Biafra, hence the activities of the Movement for the Actualisation of Sovereign State of Biafra (MASSOB) under Ralph Nwazurike and Indigenous People of Biafra (IPOB) under Nnamdi Kanu.

Perhaps, more than any other thing, official corruption has been the most worrisome issue of Nigerian governance. At a stage, it was becoming a worm until the establishment of the Economic and Financial Crimes Commission (EFCC) and Independent Corrupt Practices Commission (ICPC). Even with the establishment of the two anticorruption agencies, there have been several allegations that the executive branch has been using them to prosecute, intimidate and penalise members of opposition parties.

The present Nigerian government has, over the last six years, been struggling with the issue of National Security. The de-militarisation of the Nigerian political space since the inception of the Fourth Republic has given rise to an upsurge of robberies, armed conflicts, armed robberies, banditries, kidnapping, terrorism, etc. It appears that these problems have overwhelmed the presidency and the legislatures such that people are now clamouring for extragovernmental assemblies to solve these problems. This is usually the justification for a solemn National Assembly otherwise known as National Sovereign Conference which its advocate had designed to negotiate the basis for our association as a country. To many, such a conference of different ethnic nationalities will be politically expedient if only to redefine the Nigerian statehood and visit its socio-political re-engineering. The political restructuring becomes imperative given quasi-federal system of governance foisted on the country by the 1999 Constitution. The problem of poor political architecture of the country becomes worsened by the day, because neither the executive nor the legislature has been able to initiate any bill that could ameliorate or reverse the deteriorating situation.

\section{The Economy}

On the economic front, the country has been steadily on the decline. The Buhari government, no doubt, has been able to retrieve stolen funds through the activities of the EFCC and ICPC. However, a cursory observation of the political economy of the country shows that for every one step made forward during the Goodluck Jonathan era of 2011 - 2015, President Muhammadu Buhari had made two steps backward. For instance, inflation grew from nine percent (9\%) at the twilight of Jonathan's Administration in 2015 to $17.55 \%$ in 2016; 15.37\% in 2017 and $11.35 \%$ in May 2019 (Ibrahim 2019). It must be borne in mind, that most of the budgets since the inception of the fourth republic have not really benefited majority of the people; in fact, a significant proportion of the public funds, more often than not, usually found their ways into private pockets of politicians, their compradors, big time business elites who were awarded contracts for unexecuted projects such that the country is littered with uncompleted projects.

In the last ten years, one can arguably contend that the annual budgets, have not impacted significantly on the masses. In other words, the so-called budget had not bailed them out of socio-economic and political doldrums which successive governments had inflicted on them. The main areas where most of the budgets under Buhari's presidency had gone are debt servicing and capital expenditure such as office buildings, furniture, military hardware to fight Boko Haram, military universities in the Northeast, roads and rails. In terms of road and rails construction, they only generated less than 79,000 jobs, majority of which were part-term or casual labourers (Ibrahim, 2019). This must necessarily be viewed against the backdrop of a country of about 200 million, in which $60 \%$ of its population is unemployed youths. It must be emphasised that many of the projects embarked upon are funded through loans (especially from China in the area of airports construction in Lagos and Abuja, rail roads from Abuja to Kaduna; Lagos to Ibadan, and so on. The overall effects of these projects on the economy in terms 
of citizens' empowerment, spending, and so on are minimal. Indeed, the economic atmosphere of Nigeria is gloomy. There is paucity of financial experts who need to set the economy on a good path. The working class is totally disenchanted, the country's currency (Naira) has irretrievably lost its value. Industrial unrests are on its peak, especially over minimum wage in the recent time.

The current global coronavirus pandemic has adversely affected Nigeria's economy. Nigeria, being an importdependent economy, relies mainly in recent time on China for most of its manufacturing goods like healthcare products, construction materials, household products, etc. Indeed, Nigeria relies on China for its foreign loans and construction workers for roads and railways. The epidemic (Coronavirus) is widely believed to have originated in China's Wuhan city. This has affected the flow of human and vehicular traffic from China to Nigeria, hence the delay in Nigeria's China-built rail projects, especially the $150 \mathrm{~km}$ railway line between Lagos and Ibadan, which is being handled by state-owned China Civil Engineering Construction Corporation (CCECC).

\section{Political Parties}

The 1999 elections that ushered in Nigeria's Fourth Republic witnessed the emergence of the People's Democratic Party (PDP) as the overall winner of the election. The other subsequent elections did not change the electoral fortune of PDP, such that it became a political game of PDP and the rest of political parties to the extent that the party (PDP) held sway for sixteen (16) uninterrupted years. However, Nigeria had little (if anything) to show for the period in question as PDP the ruling party then ran amok with kleptocrats and arrogant treasury looters with zero concern for the development of human beings (Gbadegesin 2020). For instance, the security funds earmarked for anti-terrorism were largely used for political campaigns and largesse for party faithfuls. Similarly, the party (PDP) leadership could not account for multi-million dollars invested in the power sector.

By 2015, the generality of the country was fed up with the PDP, the opposition parties made up of the Action Congress of Nigeria (ACN), Congress for Progressive Change (CPC), All Nigeria Peoples Party (ANPP), and a faction of All Progressives Grand Alliance (APGA) realizing this lacuna in the body politic, hurriedly fused together as All Progressives Congress (APC) for the purpose of wrestling power from PDP at the state and federal levels.

In the main, APC was able to win the 2015 election with its 'change' mantra and its well-articulated manifestoes of delivering economic property through the instrumentality of moral probity in governance, party discipline, compassionate policy choices, diversified economy, strong determination to battle wrong, fight the war against corruption to its logical conclusion, prioritisation of constitutional amendment to devote power to states for a more balanced development otherwise known as political restructuring of the Nigerian federation.

Indeed, many politicians of PDP infiltrated APC, knowing that political defeat of the former was inevitable. Hence, friction broke out especially over the allocation of the spoils of office in the presidency as well as the National Assembly. The APC is faced with internal contradictions such that there is little or no difference between it and the PDP. Both parties are ideologically deficient. The political class that operate the parties are less committed. There is high political traffic between APC and PDP, and politicians and their follower's desert one party for another with reckless abandon.

In the bid for their avarice, the politicians have muddled up the office of the executive and the legislature. Other contradictions within the APC are intraparty conflicts which have largely weakened the party and led to the loss of Oyo, Rivers, Bayelsa and Zamfara States. The party (APC) also has a lot of issues to contend with in Ondo and Edo States. Of particular note is the division between APC's National Chairman, Adams Oshiomhole (who was former Governor of Edo State and his successor, Governor Godwin Obaseki. The differences between the two of them (Oshiomhole and Obaseki) factionalised the legislature into two camps. The Governor ignored the fifteen members in Oshiomhole's camp, while he proclaimed the House of Assembly in June 2019 with only nine members who are loyal to him. It is undemocratic and perhaps patently absurd. In this way, the Governor may have turned himself to a leviathan, as people from fifteen (15) constituencies have been kept out from legislative process of the state.

Indeed, what the above episode portends is political impunity, leading to recklessness in the governing process of the country. It is quite fashionable for the governors to seek election at the Senate after the expiration of their term of office; and for the popular legislators to seek the office of the governor of a state. In fact, the National Assembly (especially Senate) has become a political refuge for fugitive governors, many of whom were picked, charged and convicted through the EFCC by a court of competent jurisdiction especially the Supreme Court.

It is an open secret that the National Assembly is self-accounting in its budgets and expenditure. It is such that the National Assembly's annual budget (Obasanjo 2014) is shrouded in mystery, leading to tax payers maintaining a 
senator with over N300 million and a member of House of Representatives with over N200 million per annum in a country where millions of Nigerians make less than N100 per day, aggregating to 36,400 per annum. It is widely believed that Nigeria's political executives and the legislatures are the highest paid political class (public servants) in the world.

The legislature in its self-seeking bid had sent a bill to the National Assembly to extend immunity to cover principal officers of the National Assembly, such as the Senate President, Deputy Senate President, the Speaker House of Representatives and the Deputy Speaker, House of Representatives. The move was made to put them at par with the Executive branch. Section 308(3) of Nigeria's Constitution of 1999 (as amended) provides immunity for the President, Vice President, state governors and their deputies. The intention of the immunity granted the Executive was to excuse them from distractions from litany of litigations which may distract them from their critical role of governance.

The immunity which legislators enjoy all over the world is freedom from persecution for whatever they say on the floor of parliament. The immunity being sought if granted will make a mockery of representative democracy in Nigeria. It will translate the leadership of the legislature to a tiny oligarchy that can neither be touched nor recalled by their constituencies contrary to the norms of representative or constitutional democracy worldwide.

Indeed, the Nigeria's political landscape is riddled with unmitigated socio-economic and political infractions. There is the need for a complete overhauling and re-engineering of the state apparatus, which to our mind may go beyond what the executive and legislature can handle. Not even the judiciary is spared of corruption. At the peak of its (judiciary) corruption, a Chief Justice of the Supreme Court had to be involuntarily retired from the Public Service. As Obasanjo (2014) averred that 'for quite some time I did not believe the story of 'brown envelope' for Nigerian journalists and media staff, just as I did not believe the existence of corruption in the judiciary (emphasis mine). A friend described my views in those respects as archaic. But when I was given chapters and verses by the victims of corruption in those two professions, I shuddered.'

The above scenario portrays Nigeria, as a country that trots towards a failed state. As Obasanjo (2014) warns that a failed state is not an overnight event, it begins slowly before a precipitous descent.

Be that as it may, the real issue is how do we curb the slipshod of governance in Nigeria? How can the country be resilient or revitalised? These and other questions are what this work will engage itself hereafter.

\section{Conclusion: Towards a Resilient Country}

The first thing to consider is the 1999 Constitution of Nigeria. The constitution in question suffers from selfcontradictions. In the first instance, it is supposed to be the peoples' constitution, but the Nigerian populace had no input in its making. The said constitution was hurriedly foisted on Nigerians by a hurriedly departing military junta of General Ibrahim Babangida. The 1999 Constitution is essentially a quasi-federal document, which from all intents and purposes is antipodal to constitutional democracy. Hence, there is need for a congregation of constituent's assembly to fashion out a new constitution for the people.

The Nigerian state is being governed in a centralised model. While the present thirty-six state structure is being maintained, there is the need to re-model its security architecture along six geo-political models of North West, North East, North Central, South East, South West and South-South. The Southwestern states consisting of Lagos, Ogun, Oyo, Osun, Ekiti and Ondo States have evolved what is known as the Western Nigeria Security Network (WNSN) otherwise known as Operation Amotekun. It is meant to confront, contain and possibly eradicate burgeoning criminal menace, terrorist's herdsmen, armed bandits and kidnappers in the region. Other geopolitical zones are expected to have their own and work in synergy with one another.

There is also the need to have state and local government police to work in tandem with the existing Nigeria Police Force (NPF). The NPF is overstressed, overworked, over-centralised and poorly equipped to be effective in a fast country like Nigeria.

The Nigerian state is presently anomic based on the breakdown or near collapse of standard values, morals, decency, etc. This is the more reason why we struggle with corruption in the public sector. People seem to define corruption selectively depending on who is the victim of the so-called corruption. Hence, there is the need for us as a country to espouse collectively supported morality and this should be clearly articulated and documented in our Constitution and statutes, etc. The judiciary, in the dispensation of justice, should be blind.

The National Assembly, as constituted, is corrupt such that its oversight function, according to Obasanjo (2014), has been used, overused and abused for extortion. Hence, there is need to police the police by inventing an extralegislative institution which can be christened National Assembly Audit Standards Authority or Commission to audit, monitor, regulate, standardise and monitor the oversight function of the legislature. Such body should 
publish its findings periodically and authenticated copies should be made available to the NPF, ICPC, EFCC, Code of Conduct Bureau, etc, for possible prosecution of infractions. This act should be applicable to the other arms of government, i.e. the Executive and the Judiciary.

The legislative-executive relationship must be based (characterised) on knowledge of individuals; institutions rights, functions and limitations as provided in the Constitution. The official interaction between the legislature and the executive should necessarily be emboldened by cooperation, collaboration and partnership (in the interest of the nation as opposed to pecuniary interest) and synergy. If democracy must be used to advance the course of development in Nigeria, then there is need to have stable political parties anchored on strong ideological goals and commitment. The instances, which encourage politicians to hop cavalierly from APC to PDP and vice versa, thereby destabilising their political parties must be discouraged through appropriate electoral laws.

The electoral law also must be crafted to nurture and deepen internal or intra-party democracy. The internal democracy of each party must consist of a set of core values that all members will hold sacrosanct or inviolable no matter the level of differences among its members.

There is the need for political re-engineering of the Nigerian state. The political system needs to engender and nurture political parties that are viable, well-organised, efficiently run and transparently managed to encourage and enable periodic change of power, to discourage abuse of power and complacency on the part of the ruling political party.

There is a need to dislodge the present political class. This process of dislodgement will involve formation of new political parties of younger generation. The present political parties are clueless. For instance, there is no concrete ideological distinction between APC and PDP. Hence, electoral victory by either of them will be tantamount to exchanging one evil for the other. Except a generation of new political parties emerge in Nigeria's political horizon, our voyage to the promised land may remain an illusion. My contention is that, having tested both PDP and APC at the center, there seems to be no difference between them as both are vulnerable to corruption, insensitive to public yearnings and consequently enemies of the people that elected them to power.

Finally, the people (electorate) are the pivot of democracy worldwide. They must demand for their rights within the limits of the provision of constitutional democracy. Such rights, perhaps include, but not limited to, insisting that elected officials (the executive and legislature) abdicate their positions and face prosecution even before the expiration of their tenure. It is the path to a virile and enduring democracy.

\section{References}

Achebe, C. (1984). The Trouble with Nigeria. Edinburgh Heinemann Educational Books.

Achebe, C. (2012). There was a Country: A Personal History of Biafra. London, Allen Lane, Penguin Books.

Awotokun, K. (1998). Governance and Legislature Control in Nigeria: Lessons from the Second and Third Republics. International Scholars Publication, San Francisco.

Awotokun, K. (2012). Nigeria's Democracy and the Crisis of Political Leadership Legislative Vs Executive. In W. Bokelman et al. (Eds.), African Leadership Challenges and other Issues. Berlin, Germany, Mediateam IT Educational Publishers.

Awotokun, K. (2020). The Emerging pattern of Metropolitan Governance of Lagos: Its Neighbours and Environmental Sustainability in the $21^{\text {st }}$ century Nigeria. Journal of Sustainability and Environment, 5(3). https://doi.org/10.22158/se.v5n4p1

Awotokun, K. (2020). The Nigeria's Presidentialism and the Burden of Profligacy in an inchoate Constitutional Democracy. Mediterranean Journal of Social Sciences, 11(5). https://doi.org/10.36941/mjss-2020-0053

Awotokun, K., \& Okotoni, O. (2019). Governance and Executive-Legislative Relations Since Nigeria's Fourth Republic (1999 - 2019) and Beyond. Public Administration Research Canadian Center of Social and Education, 9(2). https://doi.org/10.5539/par.v9n2p28

Birch, A. H. (1993). The Concepts and Theories of Modern Democracy. London, Routledge.

Difference Between Government and Governance. Retrieved from $\mathrm{http}: / /$ www.differencebetween.net/language/words-language/difference-between-government-andgovernance/\#ixzz6WhLMp68y

Editorials. (2020). Edo Assembly rumpus. The Nation. Lagos March 19.

Egbe, R. (2020). Judicial Review: 'When Supreme Court took Lawyers to the Cleaners'. The Nation, February 27. 
Ekpu, A. (2017). Powers of the Executive and Legislature in Budget-making Process in Nigeria: An Overview. Journal of Law, Policy and Globalisation, 57.

Gbadegesin, S. (2020), Takeaways from the APC Crisis. The Nation, March 20.

Ibrahim, K. (2019), FG's Budget: Expansionary or austerity through the backdoor? The Nation, October 22.

Ihemeje, C. C. et al. (2016). Factors Influencing the Executive and Legislative Conflict in Nigeria's Political Development. IOSR Journal of Humanities and Social Science (IOSR - JHSS), 21(8). https://doi.org/10.5539/par.v9n2p28

Kanfmann, D. (1996). World Bank. Governance Indicators: Where are we, Where should we be going?

Kaufmann, D., Aart, K., \& Massimo, M. (2006). Governance Matters vs. Governance Indicators for 1996-2005. World Bank Policy Research Department. Working Paper, No: 4012. https://doi.org/10.1596/1813-9450-3630

Keping, Y. (2018). Governance and Good Governence: A New framework for Political Analysis. Fundan Journal of Humanities and social sciences, 11(1). https://doi.org/10.1007/s40647-017-0197-4

Nwaubani, O. (2014). The Legislature and Democracy in Nigeria (1960-2003): History, Constitutional Role and Prospects. Research on Humanities and Social Sciences, 4(15).

Obasanjo, O. (2014). My Watch, Vol. 3 Lagos Kachifo Ltd.

Obidimma, A. et al. (2015). The Legislative-Executive Relations in Nigeria's Presidential Democracy. International Journal of Business and Law Research, 3(1), 71-80.

Odosghimokhe, M. (2020). Challenge of Consolidating Democracy. The Nation, March 17.

Rahman, L. (2016). Governance and Good Governance: A theoretical framework. Public Policy and Administration Research, 6(10), 40-50.

Rose-Ackerman, S. (2003). Corruption and Governance: Causes, Consequences and Reforms. London, UK Cambridge University Press.

Samuel, J. S. (2020). Coronavirus: Global Economy on Trial, Impact and the Nigerian Factor. The Nation, March 12.

The Constitution of the Federal Republic of Nigeria. (1999). (As Amended), Federal Ministry of Information Abuja.

UNDP. (2005). Governance Indicators: A Users Guide.

World Bank. (1996). Governance Global Practice. World Bank Institution of Global Governance.

World Bank. (2002). Governance and Development. Washington.

World Bank. (2009). Governance Matters Vill: Aggregate and individual governance indicators 1996-2008. Working Paper No WPS4978, World Bank Publications.

World Bank. (2011). World Bank Report. Washington DC: Oxford University Press.

\section{Copyrights}

Copyright for this article is retained by the author(s), with first publication rights granted to the journal.

This is an open-access article distributed under the terms and conditions of the Creative Commons Attribution license (http://creativecommons.org/licenses/by/4.0/). 